\title{
The Influence of Interaction between the Phosphorus Fertilizer and Gibberellin on Elements Content of Lentil Crop (Lens culinaris Medic.)
}

\author{
Mohammed A.K. Al-Darkazli ${ }^{*}$, Abbas J.H. Al-Saedy ${ }^{* *}$ and Hassan A.A. Al-Saadi ${ }^{*}$ \\ *Department of Biology, Science College, Al-Mustanseryia University. \\ *** Department of Biology, Education College, Ibn Al-Haithum, Baghdad University.
}

\begin{abstract}
An experiment was conducted in the greenhouse of Biology Department, College of Education (Ibn Al-Haithum), University of Baghdad, during the growing season 2009, by using plastic pots with capacity of two $\mathrm{Kg}$ of soil. The aim of the research was to s tudy the effect of different levels of diamonium phosphate fertilizer as phosphorus source and increased concentrations of gibberellin on elements content $\mathrm{N}, \mathrm{P}, \mathrm{K}, \mathrm{Ca}$ and soluble carbohydrate percentage in vegetative part of lentil cultivar (Barka). Treatments comprised of three levels of fertilizer $(0,0.16,0.32) \mathrm{g} / \mathrm{pot}$ this equal to $(0,40,80) \mathrm{kg} / \mathrm{do}$., three concentrations of $\mathrm{GA}_{3}(0,50,100) \mathrm{ppm}$ and their interaction. The factorial experiment according to complete randomized design with three replicates. Results showed that significant differences by increase fertilizer levels, gibberellin concentrations and their interaction. The preference was for interaction of two mentioned above factors more than each one alone. Treatment with $(0.32 \mathrm{~g} /$ pot fertilizer and $100 \mathrm{ppm}$ gibberellin) gave the highest content of elements studied as compared with other treatments, since treatment with $(0.32 \mathrm{~g} /$ pot fertilizer and $50 \mathrm{ppm}$ gibberellin) gave the highest soluble carbohydrate percentage as compared with other treatments.
\end{abstract}

Keywords: DAP fertilizer, $\mathrm{GA}_{3}$ and lentil.

\section{Introduction}

Phosphorus is one of the most essential elements for the plant after nitrogen since it plays a significant role in several physiological and biochemical plants activities (1). However, the avaibility of this element for plants is limited because of different reasons like: slow mobility in the soil, interaction with other elements and soil $\mathrm{pH}(2)$, therefore it's recommended to use different phosphorus fertilizers to enhancement growth of plant.

Hussaini et al. (3) showed that the level 40 $\mathrm{kg} / \mathrm{do}$. of single super phosphate fertilizer significantly increased $\mathrm{N}, \mathrm{P}, \mathrm{K}, \mathrm{Ca}$ content in maize. Zeidan (4) founded that the level $60 \mathrm{~kg} / \mathrm{do}$. of triple super phosphate fertilizer significantly increased $\mathrm{N}, \mathrm{P}$ and $\mathrm{K}$ content in lentil. Similar results showed for other researchers such as Mehrvarz and Chaichi in Barley (5) and Al-Gizawy and Mehasen in Faba Bean (6). Studies also noted that gibberellin $\left(\mathrm{GA}_{3}\right)$ hormone is active elements uptake and organic compounds building. Ibrahim et al. (7) showed that $100 \mathrm{ppm}$ of $\mathrm{GA}_{3}$ gave a significant increase in $\mathrm{N}, \mathrm{P}$ and $\mathrm{K}$ contents in Faba Bean. Abbas (8) and Al-Saedy et al. (9) showed that $75 \mathrm{ppm}$ of $\mathrm{GA}_{3}$ caused a significant increase in carbohydrate of fenugreek and wheat respectively.

Thus, this investigation aimed to study the effect of different levels of diamonium phosphate fertilizer, $\mathrm{GA}_{3}$ and their interaction on some elements content and soluble carbohydrate percentage of lentil crop cv. Barka.

\section{Materials and Methods}

* Experimental Site and Soil Characteristics:

This study was conducted in the greenhouse of Biology department, College of Education (Ibn Al-Haithum), University of Baghdad during the growing season 2009, to study the effect of three phosphate fertilizer levels $(0,0.16,0.32) \mathrm{g} / \mathrm{pot}$, three gibberellin $\left(\mathrm{GA}_{3}\right)$ concentrations $(0,50,100) \mathrm{ppm}$ and their interaction on some elements content $(\mathrm{N}$, $\mathrm{P}, \mathrm{K}$ and $\mathrm{Ca}$ ) and soluble carbohydrate percentage of lentil crop (Lens $\underline{\text { culinaris }}$ Medic.)cv. Barka.

The Soil was brought from the biotic garden of department and cleaned by filtering through $2 \mathrm{~mm}$ sieve.

Some physical and chemical characters of the used soil analyzed according to Page et al. (10) and Table (1) showed the characters of soil. 
Table (1)

Some physical and chemical analysis of the investigated soil.

\begin{tabular}{|c|c|c|c|c|c|c|c|c|c|c|}
\hline \multicolumn{3}{|c|}{$\begin{array}{l}\text { Soil Particles } \\
\text { (g/kg soil) }\end{array}$} & \multirow{2}{*}{$\begin{array}{c}\text { Organic } \\
\text { Matter } \\
\text { g/kg soil }\end{array}$} & \multirow{2}{*}{$\begin{array}{c}\mathrm{CaCO}_{3} \\
(\%)\end{array}$} & \multirow{2}{*}{$p H$} & \multirow{2}{*}{$\begin{array}{c}E . C . \\
(d s / m)\end{array}$} & Texture & \multirow{2}{*}{$\begin{array}{c}N \\
(g / K g \\
\text { soil })\end{array}$} & \multirow{2}{*}{$\begin{array}{c}P \\
(p p m)\end{array}$} & \multirow{2}{*}{$\begin{array}{c}F e \\
(\text { ppm })\end{array}$} \\
\hline Clay & Silt & Sand & & & & & \multirow{2}{*}{$\begin{array}{l}\text { Loam } \\
\text { Slity }\end{array}$} & & & \\
\hline 201 & 530 & 260 & 8.50 & 20.50 & 7.5 & 2.35 & & 8.40 & 7.60 & 9.90 \\
\hline
\end{tabular}

* Treatments and Experimental Design:

The experiment included 27 treatments (experimental units):

1-Three levels of diamonium phosphate (DAP) $(46 \% \mathrm{P}, 18 \% \mathrm{~N}):-(0,0.16,0.32) \mathrm{g} / \mathrm{pot}$ this equal to $(0,40,80) \mathrm{kg} / \mathrm{do}$. respectively, added before planting.

2-Three concentrations of $\mathrm{GA}_{3}:-(0,50$, 100) ppm. Prepared from stock solution (dissolved $1 \mathrm{gm}$ of $\mathrm{GA}_{3}$ in $1000 \mathrm{ml}$ of D.W. and some drops of $\mathrm{NaOH}(1 \mathrm{~N})$ added in order to spread the hormone on the surface of the leaves) (11).

3-Three replicates.

The biological experiment was designed according to the complete randomized design (CRD).

Fourteen seeds were sown in each pot on $19 / 11 / 2009$ and dissolved after germination to remained six plants at each pot the concentrations of $\mathrm{GA}_{3}$ mention above sprayed once on leaves at the stage of 3-4 leaves. Spraying processes were carried out during the morning until the solutions were run off all plants by using a manual sprayer.

The first harvest was taken after 63 days $\left(\mathrm{H}_{1}-\mathrm{D}_{63}\right)$ and the second harvest was taken after 83 days $\left(\mathrm{H}_{2}-\mathrm{D}_{83}\right)$ from sowing (three plants for each harvest), oven dried at $65-70{ }^{\circ} \mathrm{C}$ for 48 hours and the dry weights were recorded, then digest 0.2 gm of dry sample for chemical analysis (12).

Contents of $\mathrm{N}, \mathrm{P}, \mathrm{K}$ and $\mathrm{Ca}$ in vegetative part was determined as follows as: $\mathrm{N} \%$ was determined by the microkjeldahl methods (13), P\% was determined by using spectrophotometer (14), K\% was determined by using flame photometer (10) and $\mathrm{Ca} \%$ was determined according (15), than calculated the elements content according to the equation:

Element content $(\mathrm{mg} / \mathrm{g})=$ Element concentration $(\%) \times$ Total dry weight $\times 10(13)$.
Soluble carbohydrate percentage determined by using phenol sulfuric acid method (16).

The least significant difference (LSD) was used to compare between means (17).

\section{Results and Discussion}

In Tables $(2,3,4,5)$ it can be observed that there was a significant increase in the $\mathrm{N}, \mathrm{P}, \mathrm{K}$ and $\mathrm{Ca}$ contents in vegetative part with increase of phosphorus fertilizer without $\mathrm{GA}_{3}$ sprayed, $\mathrm{GA}_{3}$ sprayed without phosphorus fertilizer and the interaction in both harvests.

In the phosphorus fertilizer without $\mathrm{GA}_{3}$ sprayed, the significant increasing in the $\mathrm{N}, \mathrm{P}$, $\mathrm{K}$ and $\mathrm{Ca}$ contents means in both harvests from (0 to 0.32$) \mathrm{g} / \mathrm{pot}$ at rate of $(\mathrm{N}: 235.01$, 125.52\%), (P: 130.58, 93.79\%), (K: 225.25, $181.88 \%)$ and $(\mathrm{Ca}: 184.32,152.32 \%)$. In the $\mathrm{GA}_{3}$ sprayed without phosphorus fertilizer, observed that the increasing in $\mathrm{GA}_{3}$ concentrations from (0 to 100) $\mathrm{ppm}$ led to a significant increasing in the N,P,K and $\mathrm{Ca}$ contents means in both harvests at rate of $(\mathrm{N}$ : 52.29, 47.12\%), (P: 36.01, 32.65\%), (K: 76.70, $69.29 \%$ ) and (Ca: 58.64, 54.66\%).

It can be noticed that the increasing in the phosphorus fertilizer with $\mathrm{GA}_{3}$ sprayed interaction from $(0 \mathrm{~g} / \mathrm{pot}$ fertilizer and $0 \mathrm{ppm}$ $\left.\mathrm{GA}_{3}\right)$ to $(0.32 \mathrm{~g} / \mathrm{pot}$ fertilizer and $100 \mathrm{ppm}$ $\mathrm{GA}_{3}$ ) led to high significant increasing in the $\mathrm{N}, \mathrm{P}, \mathrm{K}$ and $\mathrm{Ca}$ contents in both harvests at rate of $(\mathrm{N}: 449.18,237.28 \%), \quad(\mathrm{P}: 256.54$, $173.39 \%),(\mathrm{K}: 563.49,411.54 \%)$ and $(\mathrm{Ca}:$ 423.01, 314.75\%).

The results mentioned above in tables illustrate that best values were observed in $(80$ $\mathrm{g} /$ pot fertilizer and $100 \mathrm{ppm} \mathrm{GA}_{3}$ ) treatment compared with other treatments.

The increase of N,P,K and Ca contents may be due to the effect of phosphorus fertilizer on increasing biomaterial building like:- amino 
and nucleic acids, nucleotides, phospholipids and enzymes, thus this requires increase nutrients uptake from soil to plant (1). Also, phosphorus is important in developing good root system of lentil plants and capacity of root to absorbance more N,P,K and $\mathrm{Ca}$ accordingly their contents increased by phosphorus application (18).

Besides, $\mathrm{GA}_{3}$ has effect the increasing of cell division and cell enlargement, merstiamtic zones activation and bioactivities like:increase permeability of membranes (19). Therefore, that require increase nutrients uptake from soil to plant.

The results agreed with those obtained by Hussaini et al. in maize (3), Zeidan in lentil (4), Mehrvarz and Chaichi in barley (5) and Ibrahim et al. in Faba bean (7).

Table (2)

Effect of DAP fertilizer, $\mathrm{GA}_{3}$ sprayed and the interaction on nitrogen content (mg/g) of lentil crop.

\begin{tabular}{|c|c|c|c|c|c|c|c|c|}
\hline \multirow{3}{*}{$\begin{array}{c}\text { DAP } \\
\text { Fertilizer level } \\
(\mathrm{g} / \mathrm{pot})\end{array}$} & \multicolumn{8}{|c|}{ GA $_{3}$ concentration (ppm) } \\
\hline & \multicolumn{4}{|c|}{$H_{1}-D_{63}$} & \multicolumn{4}{|c|}{$H_{2}-D_{83}$} \\
\hline & 0 & 50 & 100 & Average & 0 & 50 & 100 & Average \\
\hline 0 & 10.41 & 15.99 & 19.01 & 15.14 & 44.72 & 54.60 & 60.23 & 51.85 \\
\hline 0.16 & 20.86 & 24.89 & 33.39 & 26.38 & 64.31 & 72.45 & 78.77 & 71.84 \\
\hline 0.32 & 40.68 & 54.30 & 57.17 & 50.72 & 82.79 & 130.65 & 137.34 & 116.93 \\
\hline Average & 23.98 & 31.73 & 36.52 & & 62.61 & 85.90 & 92.11 & \\
\hline $\begin{array}{l}\text { LSD } \\
(0.05)\end{array}$ & \multicolumn{4}{|c|}{$\begin{array}{c}\mathrm{DAP}=0.17 \\
\mathrm{GA}_{3} \times \mathrm{DAP}=0.29\end{array}$} & \multicolumn{4}{|c|}{$\begin{array}{c}\mathrm{DAP}=0.23 \\
\mathrm{GA}_{3} \times \mathrm{DAP}=0.40\end{array}$} \\
\hline
\end{tabular}

Table (3)

Effect of DAP fertilizer, $\mathrm{GA}_{3}$ sprayed and the interaction on phosphorus content $(\mathrm{mg} / \mathrm{g})$ of lentil crop.

\begin{tabular}{|c|c|c|c|c|c|c|c|c|}
\hline \multirow{3}{*}{$\begin{array}{c}\text { DAP } \\
\text { Fertilizer level } \\
(\mathrm{g} / \mathrm{pot})\end{array}$} & \multicolumn{8}{|c|}{$\mathrm{GA}_{3}$ concentration (ppm) } \\
\hline & \multicolumn{4}{|c|}{$H_{1}-D_{63}$} & \multicolumn{4}{|c|}{$\mathrm{H}_{2}-\mathrm{D}_{83}$} \\
\hline & 0 & 50 & 100 & Average & 0 & 50 & 100 & Average \\
\hline 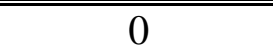 & 1.68 & 2.60 & 2.97 & 2.42 & 6.54 & 8.06 & 9.08 & 7.89 \\
\hline 0.16 & 3.15 & 3.95 & 4.74 & 3.95 & 10.62 & 13.82 & 12.15 & 12.20 \\
\hline 0.32 & 5.25 & 5.50 & 5.99 & 5.58 & 12.32 & 15.66 & 17.88 & 17.88 \\
\hline Average & 3.36 & 4.02 & 4.57 & & 9.83 & 12.51 & 13.04 & \\
\hline $\begin{array}{l}\text { LSD } \\
(0.05)\end{array}$ & & $\begin{array}{r}\mathrm{GA} \\
\mathrm{DA} \\
\mathrm{GA}_{3} \times \mathrm{I} \\
\end{array}$ & $\begin{array}{l}0.20 \\
0.20 \\
=0.3 \\
\end{array}$ & & & $\begin{array}{r}\mathrm{GA} \\
\mathrm{DA} \\
\mathrm{GA}_{3} \times \mathrm{I} \\
\end{array}$ & $\begin{array}{l}0.17 \\
0.17 \\
P=0.2\end{array}$ & \\
\hline
\end{tabular}


Table (4)

Effect of DAP fertilizer, $\mathrm{GA}_{3}$ sprayed and the interaction on potassium content $(\mathrm{mg} / \mathrm{g}$ ) of lentil crop.

\begin{tabular}{|c|c|c|c|c|c|c|c|c|}
\hline \multirow{3}{*}{$\begin{array}{c}\text { DAP } \\
\text { Fertilizer level } \\
(\text { g/pot })\end{array}$} & \multicolumn{8}{|c|}{$\mathrm{GA}_{3}$ concentration (ppm) } \\
\hline & \multicolumn{4}{|c|}{$H_{1}-D_{63}$} & \multicolumn{4}{|c|}{$H_{2}-D_{83}$} \\
\hline & 0 & 50 & 100 & Average & 0 & 50 & 100 & Average \\
\hline 0 & 8.08 & 13.63 & 17.75 & 13.15 & 25.74 & 35.88 & 39.60 & 33.74 \\
\hline 0.16 & 18.27 & 22.75 & 32.64 & 24.55 & 41.01 & 48.51 & 57.26 & 48.93 \\
\hline 0.32 & 32.15 & 42.20 & 53.61 & 42.77 & 68.26 & 84.37 & 131.67 & 94.77 \\
\hline Average & 19.62 & 26.19 & 34.67 & & 45.00 & 56.25 & 76.18 & \\
\hline $\begin{array}{c}\text { LSD } \\
(0.05)\end{array}$ & \multicolumn{4}{|c|}{$\begin{array}{c}\mathrm{GA}_{3}=0.17 \\
\mathrm{DAP}=0.17 \\
\mathrm{GA}_{3} \times \mathrm{DAP}=0.29\end{array}$} & \multicolumn{4}{|c|}{$\begin{array}{c}\mathrm{GA}_{3}=0.13 \\
\mathrm{DAP}=0.13 \\
\mathrm{GA}_{3} \times \mathrm{DAP}=0.23\end{array}$} \\
\hline
\end{tabular}

Table (5)

Effect of DAP fertilizer, $\mathrm{GA}_{3}$ sprayed and the interaction on calcium content (mg/g) of lentil crop.

\begin{tabular}{|c|c|c|c|c|c|c|c|c|}
\hline \multirow{3}{*}{$\begin{array}{c}\text { DAP } \\
\text { Fertilizer level } \\
(\text { g/pot })\end{array}$} & \multicolumn{8}{|c|}{$\mathrm{GA}_{3}$ concentration (ppm) } \\
\hline & \multicolumn{4}{|c|}{$H_{1}-D_{63}$} & \multicolumn{4}{|c|}{$\mathrm{H}_{2}-\mathrm{D}_{83}$} \\
\hline & 0 & 50 & 100 & Average & 0 & 50 & 100 & Average \\
\hline 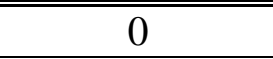 & 7.30 & 11.86 & 14.32 & 11.16 & 30.38 & 39.00 & 47.58 & 38.99 \\
\hline 0.16 & 16.87 & 20.16 & 26.78 & 21.27 & 59.00 & 58.94 & 74.61 & 64.18 \\
\hline 0.32 & 25.80 & 31.20 & 38.18 & 31.73 & 71.10 & 97.90 & 126.00 & 98.33 \\
\hline Average & 16.66 & 21.07 & 26.43 & & 53.49 & 65.20 & 82.73 & \\
\hline $\begin{array}{l}\text { LSD } \\
(0.05)\end{array}$ & \multicolumn{4}{|c|}{$\begin{aligned} \mathrm{GA}_{3} & =0.27 \\
\mathrm{DAP} & =027\end{aligned}$} & \multicolumn{4}{|c|}{$\begin{array}{c}\mathrm{DAP}=0.24 \\
\mathrm{GA}_{3} \times \mathrm{DAP}=0.41\end{array}$} \\
\hline
\end{tabular}

Also, data presented in Table (6) showed that there was significant increasing in the soluble carbohydrate percentage with the increasing in each of phosphorus fertilizer without $\mathrm{GA}_{3}$ sprayed, $\mathrm{GA}_{3}$ sprayed without phosphorus fertilizer and their interaction in both harvests, respectively.

In the phosphorus fertilizer without $\mathrm{GA}_{3}$ sprayed, there was significant increasing in soluble carbohydrate percentage for $0.32 \mathrm{~g} / \mathrm{pot}$ level which were $(4.37,3.06 \%)$ in both harvests, respectively. While, the least was observed in the $0 \mathrm{~g} /$ pot level which were $(2.17$, $1.80 \%$ ) in both harvests, respectively.

The same table showed that all concentrations of $\mathrm{GA}_{3}$ affected significantly on soluble carbohydrate percentage. The highest average recorded at $100 \mathrm{ppm}$ concentration with increasing ratio reached to (45.16, $27.27 \%$ ) in both harvests, respectively compared with 0 ppm concentration.

Table (6) showed clearly that the interaction between phosphorus fertilizer and $\mathrm{GA}_{3}$ sprayed was significant for both harvests, and highest value recorded in treatment $\left(0.32 \mathrm{~g} /\right.$ pot fertilizer and $\left.50 \mathrm{ppm} \mathrm{GA}_{3}\right)$ which reached to $(4.66,3.22 \%)$ in both harvests, respectively. While, the lowest recorded in treatment $\left(0 \mathrm{~g} /\right.$ pot fertilizer and 0 ppm $\left.\mathrm{GA}_{3}\right)$ in both harvests.

The positive response of lentil plants (increase soluble carbohydrate percentage) to phosphorus fertilization may be due to increase of nutrients uptake which builds carbohydrate, photosynthesis rate and enzymes activity (2). While, $\mathrm{GA}_{3}$ affected on increase of leaf 
expansion, delay senescence and nutrients uptake which builds carbohydrate (20). The results agreement with Al-Gizawy and
Mehasen in Faba Bean (6), Abbas in fenugreek (8) and Al-Saedy et al. in wheat (9).

Table (6)

Effect DAP fertilizer, $\mathrm{GA}_{3}$ sprayed and the interaction on soluble carbohydrate percentage (\%) of lentil crop.

\begin{tabular}{|c|c|c|c|c|c|c|c|c|}
\hline \multirow{3}{*}{$\begin{array}{c}\text { DAP } \\
\text { Fertilizer level } \\
(\mathrm{g} / \mathrm{pot})\end{array}$} & \multicolumn{8}{|c|}{$\mathrm{GA}_{3}$ concentration (ppm) } \\
\hline & \multicolumn{4}{|c|}{$H_{1}-D_{63}$} & \multicolumn{4}{|c|}{$H_{2}-D_{83}$} \\
\hline & 0 & 50 & 100 & Average & 0 & 50 & 100 & Average \\
\hline 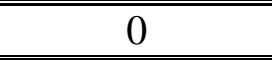 & 1.17 & 2.34 & 3.01 & 2.17 & 1.07 & 1.88 & 2.45 & 1.80 \\
\hline 0.16 & 2.13 & 2.77 & 3.51 & 2.80 & 2.10 & 2.22 & 2.68 & 2.33 \\
\hline 0.32 & 4.15 & 4.66 & 4.29 & 4.37 & 3.11 & 3.20 & 2.86 & 3.06 \\
\hline Average & 2.48 & 3.26 & 3.60 & & 2.09 & 2.43 & 2.66 & \\
\hline $\begin{array}{c}\text { LSD } \\
(0.05)\end{array}$ & \multicolumn{4}{|c|}{$\begin{array}{c}\mathrm{GA}_{3}=0.08 \\
\mathrm{DAP}=0.08 \\
\mathrm{GA}_{3} \times \mathrm{DAP}=0.14\end{array}$} & \multicolumn{4}{|c|}{$\begin{array}{c}\mathrm{GA}_{3}=0.13 \\
\mathrm{DAP}=0.13 \\
\mathrm{GA}_{3} \times \mathrm{DAP}=0.23\end{array}$} \\
\hline
\end{tabular}

\section{References}

[1] R.M. Devlin and F.H. Witham, Plant Physiology. Dar Al-Arabia for publisher and distribution, Al-Qahera. $4^{\text {th }}$ edition, 1998, pp. 94-110, (In Arabic).

[2] H. Marschaner, Mineral Nutrition of Higher Plant. Academic Press, INC. London, Ltd., 1986, pp. 86-97.

[3] M.A. Hussaini, V.B. Ogunleda, A. A. Ramalan and A.M. Falaki, Mineral composition of dry season maize (Zea mays L.) in response to varying levels of nitrogen, phosphorus and irrigation at Kadawa, Nigeria. World J. of Agric. Sic, Vol. 4, NO. 6, 2008, pp. 775-780.

[4] M.S. Zeidan, Effect of organic manure and phosphorus fertilizers on growth, yield and quality of lentil plant in sandy soil. Res. J. of Agric. and Bio. Sic., Vol.3, NO.6, 2007, pp.748-752.

[5] S. Mehrvarz and M.R. Chaichi, Effect of phosphorus solubilizing micro organism and phosphorus chemical fertilizer on forage and grain Quality of barley (Hordum vulgare L.). Am-Euras. J. Agric. and Enivron. Sci., Vol.3, NO 6, 2008, pp. 855-860.

[6] N.Kh.B. Al-Gizawy and S.A.S. Mehasen, Response of Faba Bean to bio, mineral phosphorus fertilizers and foliar application with zinc. World applied Sci., J., Vol.6, NO.10, 2009, pp.1359-1365.
[7] M.E.Ibrahim, M.A.Bekhata, A. El-Mourisi and N.A. Gafer, Improvement of growth and seed yield quality of Vicia faba L. plants as affected by application of some bioregulators. Aus. J. of Basic and Applied Sic., J., Vol. 1, NO.14, 2007, pp. 657-666.

[8] E.D. Abbas, Effect of different concentrations of Gibberellic acid $\left(\mathrm{GA}_{3}\right)$ on some morphological and physiological characteristics of fenugreek plant. M. Sci. Thesis, College, of Education, Sulaimani University, 2008, pp.68-72.

[9] A.J. Al-Seedi, A.L. Al-Arkawizi and A.A. Muhammad, The influence of the interaction between $\mathrm{GA}_{3}$ and fertilizer in growth of wheat crop. Krabla Sci., J., Vol. 3, NO. 1, 2009, pp. 274-282 (In Arabic).

[10] A.L.Page, R.H. Miller and D.R. Kenney, Methods of Soil Analysis. Part (2) $2^{\text {nd }}$ ASA. INC. Madison Wisconsin, USA, 1982, pp.111-120.

[11] W.A.M. Al-Quessi, Effect of some plant regulators on different verities of Faba Bean. Ph.D. Agric. College, Bagdad University, 1996, pp.74-85(In Arabic).

[12] A.H.Agiza, M.I. El-Hiniedy and M.E. Ibrahim, The determination of different fractions of phosphorus. Plant and Soil. Bull. Fac. Agric., Cairo University, 1960, pp. 121. 
[13] A.C.Schaffalen, A. Miller and J. C. H. Van Schouwenbury, Quick test for soil and plant analysis used by small lab. Neth. J. Agric. Sci., NO. 9, 1961, pp.2-16.

[14] K. J. Matt, Colorimetric determination of phosphorus in soil and plant materials with ascorbic acid. Soil Sci., NO. 109, 1970, pp. 214-220.

[15] N.W. Wimberley, The Analysis of Agriculture Material. Maff. Tech. Bull. London, 1968, pp.95-103.

[16] D.Herbert, P.J. Philips and R.E. Strange, Methods in Microbiology. Acad. Press, London, 1971, pp.88-93.

[17] T.M. Little and F.J. Hills, Agricultural Experimentation Design and Analysis. John Wiley and Sons. New York, 1978.

[18] A.M.A. Okaz, E.A.El-Ghareib, W. Kadry, A.Y. Negm and F.A.F. Zahran, Response of lentil plants to potassium and phosphorus application in newly reclaimed dandy soils. Conf. Agron., Al-Azhar Univ., NO. 2, 1994, pp. 753-771.

[19] W.G. Hopkins and N.P.A. Huner, Introduction to Plant Physiology. $3^{\text {rd }}$ edition, Wiley international edition, USA,2004,pp.78-85.

[20] S.K. Verma and M. Verma, A text book of Plant Physiology, Biochemistry and Biotechnology. $9^{\text {th }}$ edition, India, 2008, pp.133-148.

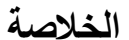

نفذت التجربة في البيت الزجاجي التابع لقسم علوم

الحياة، كلية التربية/ ابن الهيثم، جامعة بغداد خلا الهربه الموسم

الزراعي 2009 باستعمال اصص بلاستيكية ذات سعة 2 كغم

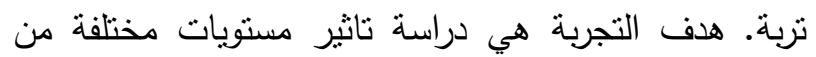

سماد كمصدر للفسفور فوسفات الامونيوم الثتائية وتراكيز

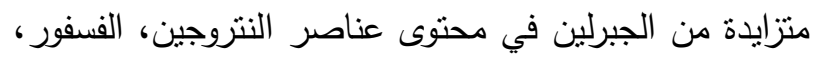

البوتاسيوم، الكالسيوم والنسبة المئوية للكربوهيدرات الذائبة

للجزء الخضري لنبات العدس صنف بركة.

شملت معاملات التجربة ثلاث مستويات من السماد

(0.32, $0.16,0)$

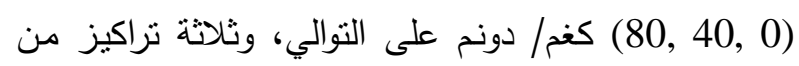

الجبرلين (100, 50, 0) جزء من المليون والتداخل بين

العاملين بموجب تجربة عاملية ذات التصميم العشوائي الكامل

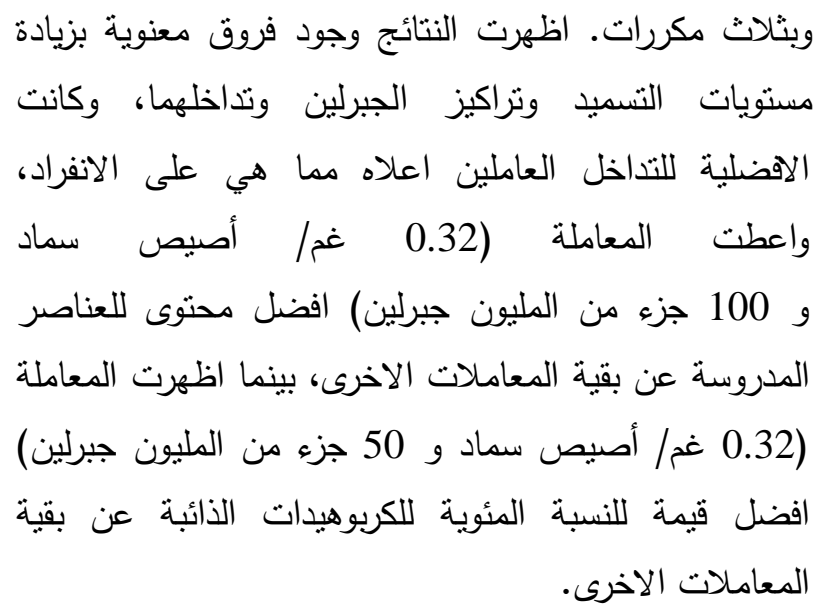

